\title{
Persistent Effects of Chemicals Used to Control Shrub Densification in Semi-Arid Savanna
}

\author{
Hugo Bezuidenhout ${ }^{1,2}$, Tineke Kraaij ${ }^{3,4} \&$ Johan Baard $^{3}$ \\ ${ }^{1}$ South African National Parks, Scientific Services, Kimberley, South Africa \\ ${ }^{2}$ Applied behavioural ecology and ecosystem research unit, UNISA, Florida, South Africa \\ ${ }^{3}$ South African National Parks, Garden Route Scientific Services, Knysna, South Africa \\ ${ }^{4}$ Nelson Mandela Metropolitan University, School of Natural Resource Management - Nature Conservation, \\ George, South Africa \\ Correspondence: Hugo Bezuidenhout, South African National Parks, Scientific Services, Kimberley office, P.O. \\ Box 110040, Hadison Park, 8306, South Africa. Tel: 27-538-325-488. E-mail: hugo.bezuidenhout@sanparks.org
}

Received: August 11, 2014 Accepted: August 21, 2014 Online Published: October 29, 2014

doi:10.5539/esr.v4n1p31 URL: http://dx.doi.org/10.5539/esr.v4n1p31

\begin{abstract}
Mokala National Park (MoNP) was proclaimed in 2007 in an area that used to be managed as a commercial wildlife and hunting farm, and prior to 2003 as a cattle and goat farm. The vegetation comprises sparse to closed woodlands and shrublands of the Savanna Biome. Shrub densification was deemed undesirable in the context of commercial farming where management objectives were to maximise production of grazing animals and to promote visibility of wildlife to tourists and hunters. Accordingly, previous landowners have attempted to eradicate prolific shrubs (particularly Senegalia mellifera) by mechanical and chemical means in certain areas during the period 1996-2004. Effects of these treatments are still apparent more than a decade later. Here we document the history of herbicide applications and other management practices in affected areas of MoNP. We furthermore explore potential ecological effects of the herbicide used ('Molopo 200GG' with active ingredient Tebuthiuron) in relation to the ecology of the most-affected shrub species, S. mellifera. We conclude with suggestions for future monitoring to establish potential long-term impacts of the chemical control.
\end{abstract}

Keywords: Acacia mellifera, bush encroachment, conservation, herbicide, Mokala National Park, protected area management, restoration, Senegalia mellifera, Tebuthiuron, South Africa

\section{Introduction}

Mokala National Park (MoNP) is one of the most recent (proclaimed 19 June 2007) additions to the suite of parks managed by South African National Parks (SANParks) and currently comprises 27571 hectares (ha). The deproclamation of Vaalbos National Park (VNP) in 2007 in the Northern Cape Province led to the establishment of MoNP in the general vicinity of VNP in an area that used to be managed as a commercial wildlife and hunting farm (Bezuidenhout, Bradshaw \& Bradshaw, in press). SANParks took over management of the farm 'Wintershoek' on 30 May 2006. Not only is the area able to support relatively high numbers of large wildlife, it also includes habitat types that were represented in VNP but not in any of the other national parks. Thus, the proclamation of MoNP helps to fulfil SANParks' mission to 'develop, manage and promote a system of national parks that represents the biodiversity and heritage assets by applying best practice, environmental justice, benefit sharing and sustainable use'. MoNP furthermore provides a tourism product that helps to promote local economic development.

VNP has consisted of two sections, the Than-Droogeveld section (18 $120 \mathrm{ha})$ situated $61 \mathrm{~km}$ north-west of Kimberley, and the smaller Gras-Holpan section (4 576 ha) $25 \mathrm{~km}$ west of Kimberley (Bezuidenhout, 1994, 1995). In November 1997 and December 1998, reports were received of a land claim that would be lodged against VNP's Than-Droogeveld section, by the Sidney-on-Vaal claimants. After the claim was legitimized, SANParks investigated five potential localities for the new national park. All investigations indicated that Wintershoek, in the Plooysburg area, was the preferred option (Koch et al., 1999). In November 2002, the land claim was gazetted. In November 2004, SANParks officially launched the negotiation process with the landowners. The submission to proclaim the Wintershoek area as a National Park was forwarded to the Minister 
of Land Affairs and signed on 30 May 2006.

Mokala is a Setswana name for the Camel Thorn tree ('kameeldoring', Vachellia erioloba E. Mey. Seigler \& Ebinger), a charismatic tree characteristic of the region. MoNP largely comprises savanna vegetation, varying from sparse to dense woodlands and shrublands (Bezuidenhout et al., in press). Senegalia mellifera (Vahl) Seigler \& Ebinger (previously Acacia mellifera) is the dominant shrub in large parts of the region and plays an important role in the ecological functioning of semi-arid savannas. It is furthermore an important food source of the black rhinoceros (Buk \& Knight, 2010), one of the endangered wildlife species in MoNP. On the other hand, tree or shrub encroachment or densification is perceived to be a significant problem in savanna areas globally, particularly in the context of commercial farming where management objectives are to maximize production of grazing animals, or to promote visibility of wildlife to tourists and game to hunters (Ward, 2005). Various measures may be employed in an attempt to combat the problem (Ward, 2005).

After proclamation of MoNP, a reconnaissance visit in August 2007 revealed that in certain areas the tree and shrub layers were dead. An investigation into the cause of the large-scale mortality of woody plant species revealed that these areas were chemically treated by the previous landowners. The aim of this note is to document the extent of, and the management history at, these treated sites within MoNP. We explore potential ecological effects of the herbicide applied in relation to the ecology of the dominant shrub species, S. mellifera. We conclude with suggestions for future monitoring to establish the potential long-term impacts of the treated areas.

\section{Study Area}

MoNP is located $\left(29^{\circ} 10^{\prime} 20.7^{\prime \prime} \mathrm{S}, 24^{\circ} 21^{\prime} 00.5^{\prime \prime}\right.$ E) in the Northern Cape Province, $80 \mathrm{~km}$ south-west of Kimberley, and west of the national road (N12) to Cape Town (Figure 1). The predominantly summer rainfall is erratic - mean annual rainfall being $415 \mathrm{~mm}$ and ranging between $304 \mathrm{~mm}$ and $622 \mathrm{~mm}$ per annum (September to August; 2008-2013, SANParks unpublished data) (Figure 2). Geographical features of MoNP comprise rolling rocky hills, undulating sandy plains, undulating calcrete plains, degraded old lands, drainage lines and a portion of the Riet River. Within these features, nine landscapes and one degraded land unit (old agricultural land) were identified (Bezuidenhout et al., in press) (Figure 1). Previous management practices included goat farming focussed in the Puntberg area, cattle farming until 2003 with rotational grazing among 33 camps, and gradual re-introduction of wildlife thereafter (W. van der Linde pers. comm., August 2007). 


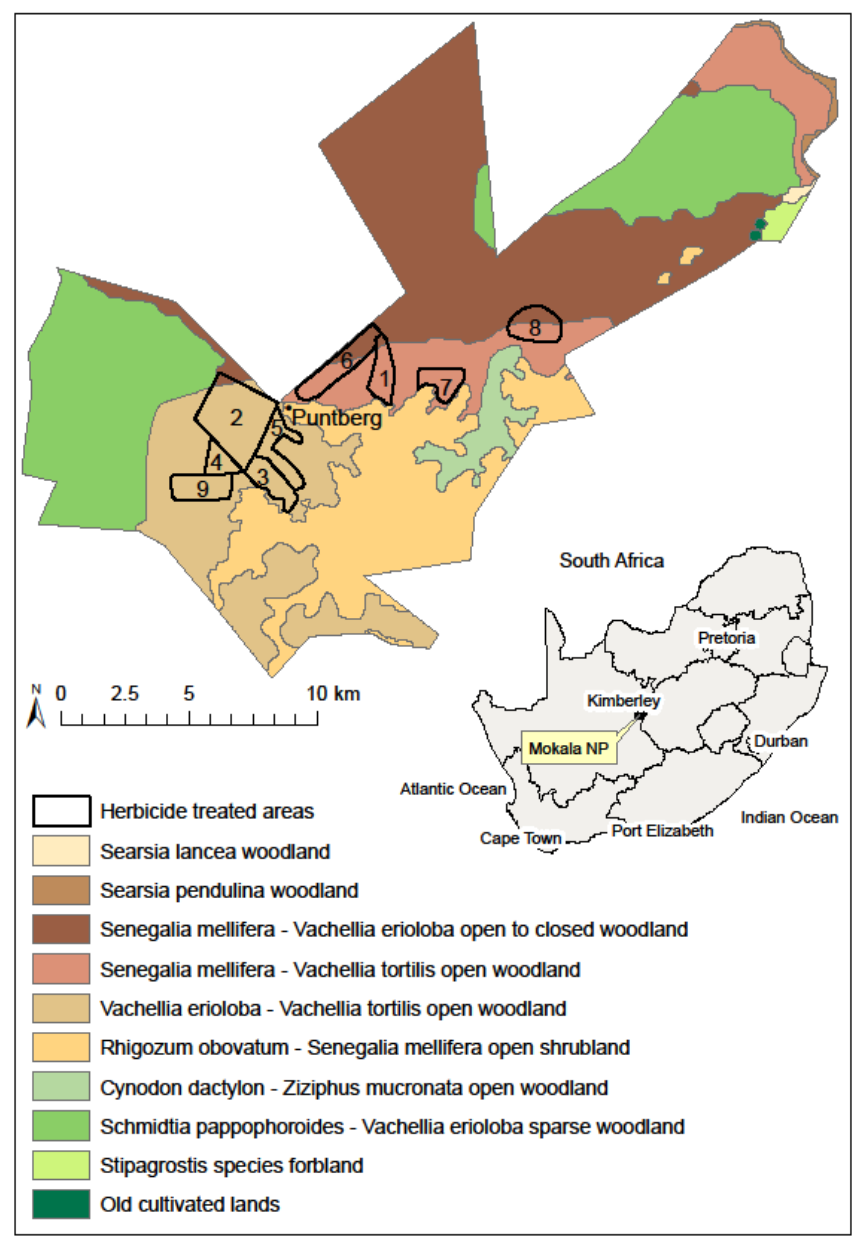

Figure 1. Vegetation landscape units (adapted from Bezuidenhout et al., in press) and the location of treated areas at Mokala National Park, South Africa. Block numbers refer to accounts of herbicide application in Table 1. Spatial accuracy of block boundaries is limited by the level of precision achievable by the relevant application methods

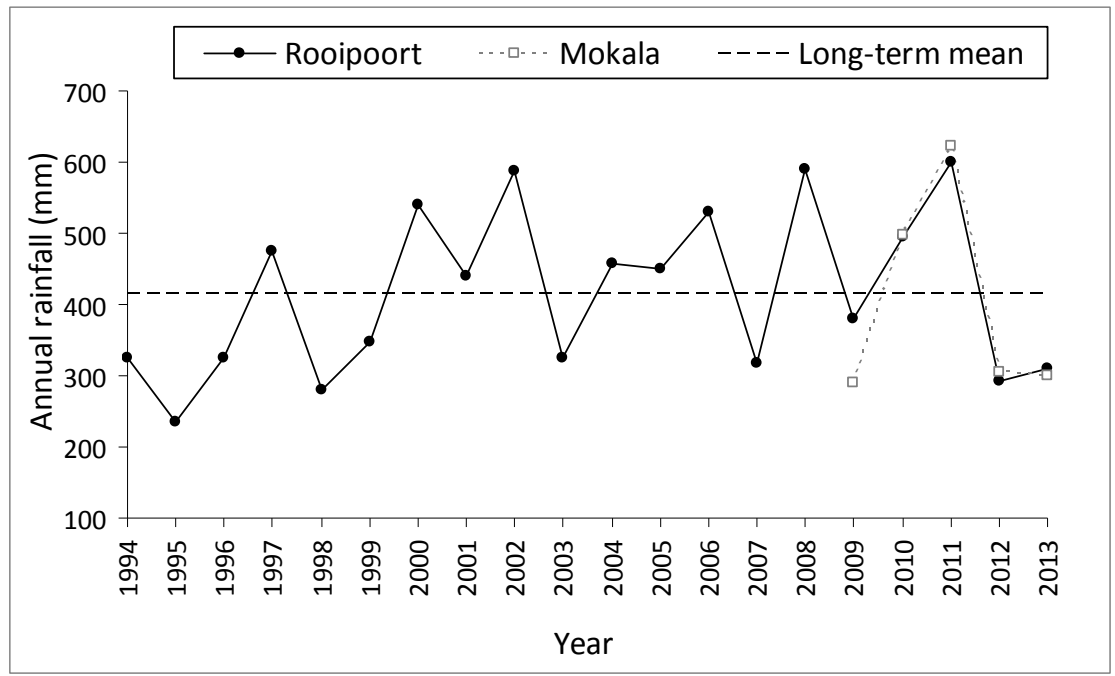

Figure 2. Annual rainfall for Mokala National Park and Rooipoort Nature Reserve ( $c a .60 \mathrm{~km}$ north-west of Mokala National Park) with annual cycles ending in August of each year. The long-term (1994-2013) mean pertains to Rooipoort 


\section{Management History at Chemically Treated Sites}

The two landscapes impacted by chemical treatment are the Vachellia erioloba - Vachellia tortilis open woodland west of Puntberg, and the Senegalia mellifera - Vachellia tortilis open woodland towards the north of Puntberg (Figure 1). The former is a sandy (clay content of soil less than 6\%) plain, and the latter a rocky (clay content of soil more than 10\%) footslope. A conspicuous landmark in MoNP is the Puntberg hill, where farming fences used to, and park-fences presently, create a bottle neck which forced domestic animals in the past, and wildlife presently, to move through a $30 \mathrm{~m}$ wide corridor. This led to trampling and degradation of the area with erosion also visible.

The rationale for the application of herbicide to woody plant species was to (i) improve accessibility, (ii) increase carrying capacity for grazers, and (iii) increase visibility for hunters in certain places. The granular form of Molopo Graslan herbicide (Molopo 200 GG product; see characteristics below) was used, largely targeting the woody plant species S. mellifera and Vachellia tortilis (Forssk.) Galasso \& Banfi (W. van der Linde pers comm.., August 2007). The method of treatment varied among areas. Plant-specific application by hand in the form of granules was at a dosage of $6 \mathrm{~kg} / \mathrm{ha}$ while granule application by aeroplane was at a dosage of $3 \mathrm{~kg} / \mathrm{ha}$. Treatments were applied on different occasions from 1996 to 2004 mostly during September and as indicated in Figure 1 and Table 1.

Table 1. History of herbicide applications and other management practices in treated areas of Mokala National Park

\begin{tabular}{|c|c|c|}
\hline $\begin{array}{c}\text { Block no. } \\
\text { Year(s) treated }\end{array}$ & $\begin{array}{l}\text { Application mode } \\
\text { Area treated }\end{array}$ & $\begin{array}{l}\text { Historical management practices } \\
\text { Soil texture }\end{array}$ \\
\hline $\begin{array}{c}1 \\
1996 \& 2003\end{array}$ & $\begin{array}{l}1996 \text { - hand application to } S \text {. mellifera } \\
\text { (some individuals missed) but not applied to } \\
\text { Boscia albitrunca; } 2003 \text { - aerial application } \\
\text { to all woody species } \\
\text { Both sides of road (east and west) treated in } \\
\text { strips (30-40 m wide and length not } \\
\text { recorded) }\end{array}$ & $\begin{array}{l}\text { Vegetation impacted by cattle } \\
\text { grazing } \\
\text { Clayey in the south and sandy } \\
\text { towards the northern section of } \\
\text { strips }\end{array}$ \\
\hline 2 & Aerial & - Vegetation impacted by goats \\
\hline 1997 & Block (size not measured) & - Sandy \\
\hline 3 & Hand & - Vegetation impacted by goats \\
\hline 1997 & $\begin{array}{l}\text { Strips ( } 30-40 \mathrm{~m} \text { wide, length not recorded) } \\
\text { in areas } 300 \mathrm{~m} \text { wide on northern and } \\
\text { southern sides of the road }\end{array}$ & - Sandy \\
\hline 4 & Aerial & - Vegetation impacted by goats \\
\hline 1998 & Block (size not measured) & - Sandy \\
\hline 5 & Hand & - Vegetation impacted by goats \\
\hline 1998 & $\begin{array}{l}\text { Strips ( } 30-40 \mathrm{~m} \text { wide) in areas } 300 \mathrm{~m} \text { wide } \\
\text { on east and north side of the road }\end{array}$ & - Clayey \\
\hline 6 & Hand & - $\quad$ Former goat camp; fire in 1995 \\
\hline 2002 & $200 \mathrm{~m}$ strip, only south side of road & - Clayey \\
\hline 7 & Aerial & - Shrubs manually cleared in \\
\hline 2003 & Block (size not measured) & $\begin{array}{l}\text { 2002; subsequently treated in } \\
2003 \\
\text { - Sandy }\end{array}$ \\
\hline 8 & Aerial & - Shrubs manually cleared in \\
\hline 2003 & Block (size not measured) & $\begin{array}{l}\text { 2002; subsequently treated in } \\
2003 \\
\text { - Sandy }\end{array}$ \\
\hline 9 & Hand & - Sandy \\
\hline 2004 & $60 \mathrm{~m}$ wide and $2 \mathrm{~km}$ long strip south of road & \\
\hline
\end{tabular}

\section{Characteristics of Molopo Herbicide}

Molopo 200GG is a local name for a South African manufactured broad-spectrum herbicide with Tebuthiuron 
$(200 \mathrm{~g} / \mathrm{kg}$ ) as active ingredient (Dow AgroSciences, 2003). The manufacturer, Dow AgroSciences LLC, sells Tebuthiuron-based products worldwide under the names Brush Bullet, EL-103, Graslan, Spike, Perflan, Herbec, Herbic and Reclaim. Tebuthiuron, a thiadiazole urea herbicide, has demonstrated excellent herbicidal activity on a broad spectrum of woody plant species at rates of $0.56-4.48 \mathrm{~kg} / \mathrm{ha}$ of active ingredient, which is equivalent to 2.8-22.0 kg/ha of Molopo product (Dow AgroSciences, 2009). After application, Molopo is dissolved by rain and then infiltrates the soil. It is a non-selective herbicide absorbed by the roots of woody plant species and translocated to the leaves by means of transpiration where it inhibits photosynthesis. Woody plant species may successively loose and regain leaves until death occurs.

Tebuthiuron is highly persistent in the soil (potentially active for up to 15 years; G. Verdoorn pers comm., 2007), and has a half-life of 12-15 months in areas with over $1000 \mathrm{~mm}$ of annual rainfall while longer half-lives may be expected in drier areas and in soils with high organic matter and clay content (Rainey \& Magnussen, 1976; Johnsen \& Morton, 1989; Dow AgroSciences, 2003). In Canada, under annual rainfall of $450 \mathrm{~mm}$, Tebuthiuron persisted in the soil for 11 years after application (Canadian Council of Ministers of the Environment, 1999). Given MoNP's annual average rainfall of just over $400 \mathrm{~mm}$ per year, persistence of the herbicide in the soil may be similarly protracted. Laboratory studies showed that higher temperature and increased soil moisture enhance break down of Tebuthiuron (Chang \& Stritzke, 1977). In areas with low rainfall, Tebuthiuron thus breaks down faster under summer rainfall regimes than under winter rainfall regimes (Dow AgroSciences, 2009). Herbicide application rates also influence persistence in the soil.

Tebuthiuron has all the characteristics of a compound with high potential for groundwater contamination as it is easily translocated by moisture in the soil (Extoxnet, 1993). In Arizona USA, 55-73\% of the applied herbicide occurred at depths of 600-900 mm (rainfall $310-450 \mathrm{~mm}$ ) nine years after application, suggesting that it may leach to, and accumulate at, the depth that rainwater penetrates (Johnsen \& Morton, 1989). This alludes to long-term re-poisoning of deep-rooted plants as their roots grow downwards. Accordingly, the manufacturer (Dow AgroSciences, 2009) concedes that Tebuthiuron may occur at soil depths of $600 \mathrm{~mm}$ and claims that some leaching of Tebuthiuron is desirable to control deep-rooted woody plant species. Conversely, in coarse soil in Arizona, Tebuthiuron only leached $75-150 \mathrm{~mm}$ into the soil after $600 \mathrm{~mm}$ of rain in 690 days (Emmerich, Helmer, Renard, \& Lane, 1984).

Adsorption of Tebuthiuron depends on soil types, it being greatest in soils with high organic matter content and high clay content (and low in sandy soils), while it is also higher in acidic soils than in neutral or alkaline soils (Dow AgroSciences, 2009). Tebuthiuron does not break down in the soil - it is not lost by volatilisation at normal soil temperatures and not decomposed by sunlight (Beste, 1983). It may only be lost from the soil by microbial decomposition (which is not considered a predominant mode of degradation), leaching, and uptake by plant species (Johnsen \& Morton, 1989).

\section{Ecology of Senegalia mellifera Relevant to the Effects of Molopo Herbicide}

Senegalia mellifera has a shallow but extensive lateral root system, extending 8-15 m from the stem parallel to the surface and at a depth of $250 \mathrm{~mm}$ (Adams, 1967). It also has a deep tap root which makes it less dependent on surface moisture (Donaldson, 1967). Herbicide present in both the shallow and deeper soil horizons may thus potentially affect the plant species. Chemical control is most effective in March (Van Niekerk \& Kotze, 1977) as treatment depends on translocation of photosynthate to the roots, which is correlated with leaf-fall. In the case of MoNP, chemical control was done during September at the start of the growing season of S. mellifera (W. van der Linde pers comm.., August 2007; Fabricius \& Van den Berg, 1993).

New recruitment of $S$. mellifera into previously treated areas (where the herbicide is no longer active) would depend on the availability of viable seed and the occurrence of conditions favourable to germination. Dispersal by ungulates of viable seeds into treated areas from adjacent sources presumably is limited as seed germination is not enhanced by ingestion. Instead, $97 \%$ mortality resulted from ingestion by cattle in another study (Donaldson, 1967). S. mellifera seed banks are ephemeral, recruitment thus being dependent on the current season's seed crop (Donaldson, 1967). The species furthermore requires exceptionally good rainfall in order to produce large crops of viable seed, while seeds may be absent, sterile or highly predated in years with low or moderate rainfall (Donaldson, 1967; Joubert, Rothauge, \& Smit, 2008). After exceptional rains, seed banks are too large for seed predators to reduce the seed bank significantly. Shrubs or trees occurring alongside roads and receivin increased runoff from road surfaces may create the impression that a large proportion of shrubs or trees reproduce annually, but this may be misleading. Seeds are released during December, before the peak rainy season (January-April). Seeds germinate easily, but above-average rainfall, with regular, evenly spaced events are required for seedling establishment, frequency of rainfall being more important than total amount of rainfall 
(Wilson \& Witkowski, 1998; Kraaij \& Ward, 2006; Joubert et al., 2008). African Senegalia and Vachellia seeds require a critical level of soil moisture for 10-14 days before emergence, while the minimum water requirements for the first two weeks of establishment are c. $3 \mathrm{~mm}$ of rainfall every second day (Wilson \& Witkowski, 1998) or $>5 \mathrm{~mm}$ per week during the establishment phase (Joubert et al., 2008). Another good rainfall season or two are required for sapling survival (Meyer, Wiegand, Ward \& Moustakas, 2007; Joubert et al., 2008). Multiple consecutive years of good rains may thus be necessary for successful recruitment of $S$. mellifera - something which may only happen a few times per century (Joubert et al., 2008). Assessment of daily rainfall data showed that since the herbicide was applied at the study area, one (January-February 2011) and perhaps a second (February 2010) period with frequent rainfall occurred that may have been suitable for seedling establishment of Senegalia or Vachellia species.

\section{Photographic Evidence}

Photographic sequences or comparisons may be useful to detect or assess vegetation change (Rohde \& Hoffman, 2010; Masubelele, Hoffman, Bond, \& Burdett, 2013). In our study, photographic evidence from chemically treated and adjacent untreated sites showed that chemical treatments resulted in large-scale mortality of shrubs, still apparent more than a decade after application (Figures 3-5). Woody species suffering the greatest mortality were S. mellifera, V. erioloba and V. tortilis. Conversely, Boscia albitrunca (Burch.) Gilg \& Gilg-Ben largely survived treatments, with live trees present ten years after treatment. The latter is a slow-growing species and should be monitored for potential delayed effects.

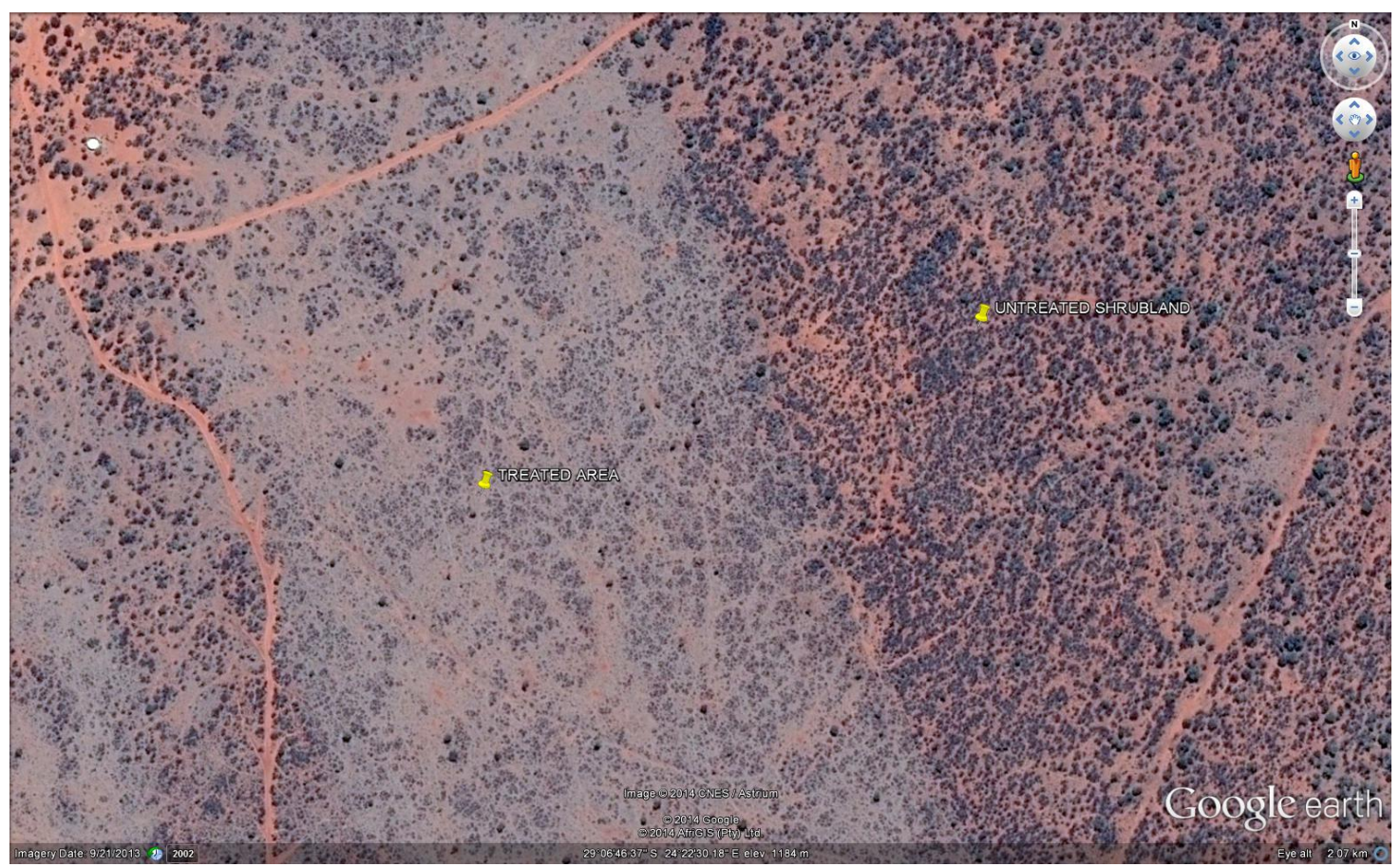

Figure 3. Google earth image (dated 21 September 2013) of block 7 (see Table 1), the treated area appearing dull grey compared to adjacent, untreated shrubland where shrubs and grassland show higher contrast 


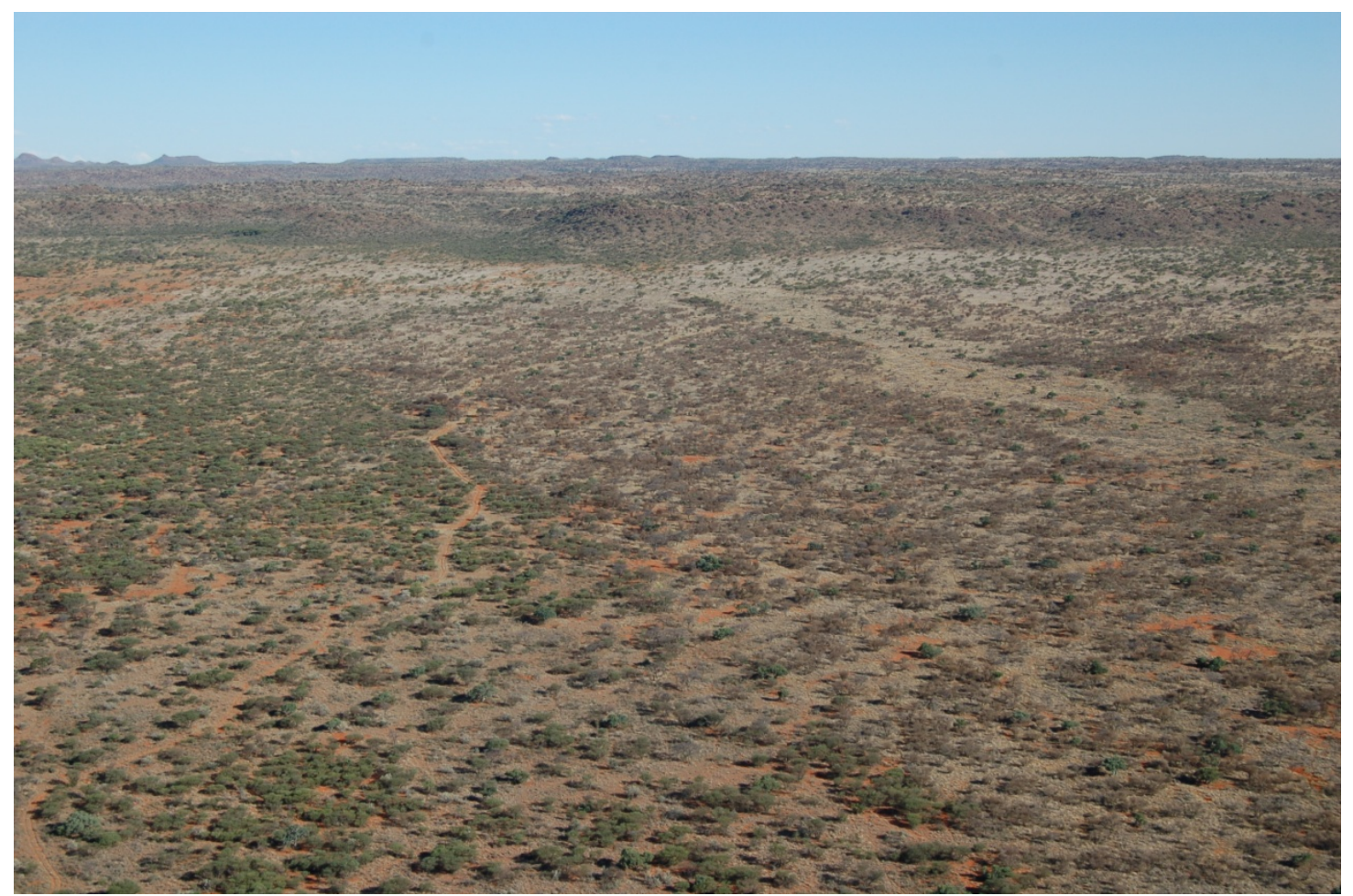

Figure 4. Aerial view (date of photo March 2007) of block 7 (see Table 1), with shrubs in the treated area appearing dull grey compared to the green shrubland in the adjacent untreated area (Photo by Hein Grobler)
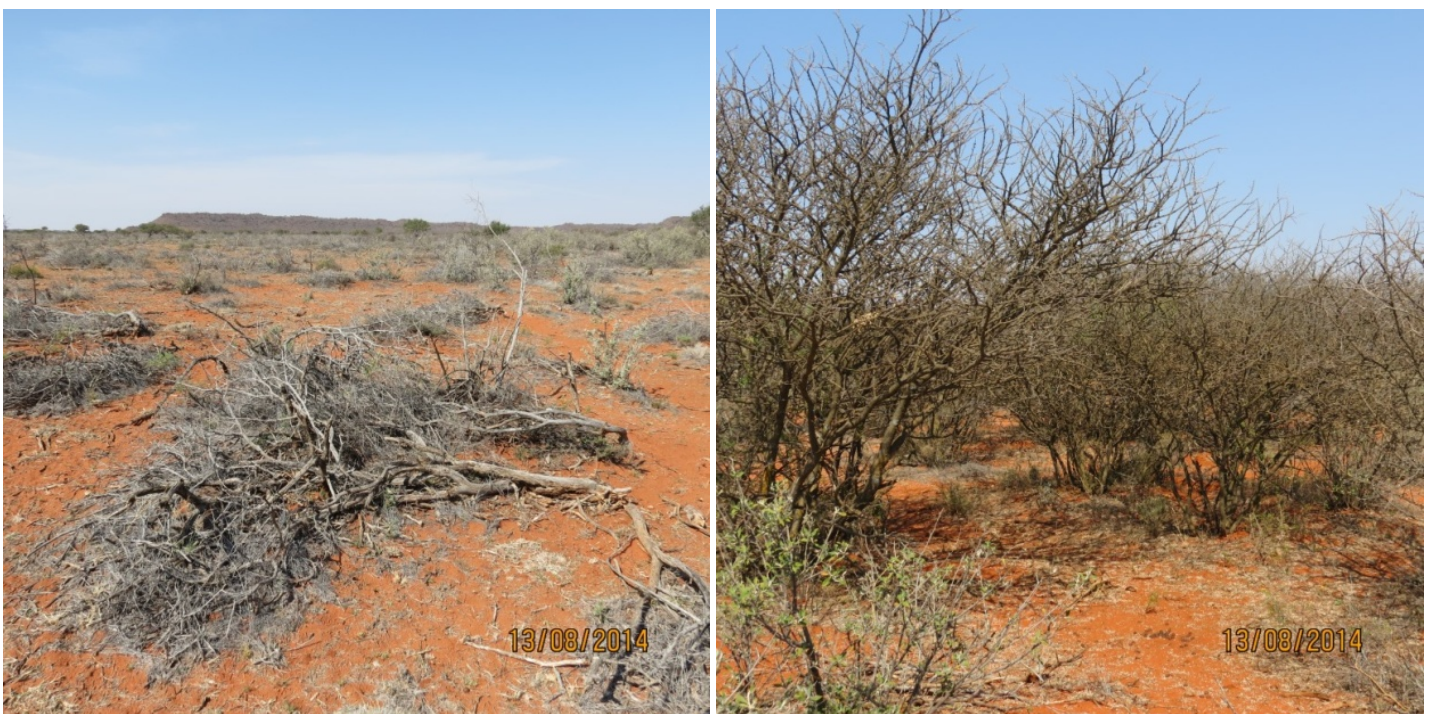

Figure 5. Ground view (date of photos August 2014) of block 7, with treated area on the left and untreated shrubland on the right (Photos by Charlie Rheinhardt)

\section{Suggestions for Further Investigations}

The following investigations should inform whether active rehabilitation measures would be required in future or whether natural recovery in the treated areas may be adequate to ensure conservation of ecological pattern and process. The level of new recruitment (seedlings) and successful early establishment (saplings) may be compared between treated and adjacent, untreated sites where nearby sources of seeds (mature shrubs) are present in both (e.g. hand application areas where some $S$. mellifera shrubs survived). Recruitment failure in both treated and untreated areas would point to a lack of viable seed or inadequate quantity or frequency of rainfall. If recruitment is successful in untreated areas only, it would suggest that the herbicide is still active and preventing recruitment 
in treated areas, despite availability of seed and the occurrence of suitable rainfall. If recruitment is evident in treated areas, it would suggest that the Tebuthiuron has either leached out of, or has been metabolised, in the shallower soil horizons where seedlings/saplings are rooted; alternatively, patches within the treated areas may have been missed during application of the herbicide.

Potential recruitment in treated areas may furthermore be quantified in relation to distance from seed source. A negative relationship would indicate that recruitment is hampered by seed availability rather than by persistence of the herbicide in the soil (or rainfall factors). Alternatively, gas chromatography with flame photometric detection (cf. Johnsen \& Morton, 1989) could detect residual activity of Tebuthiuron in different soil horizons. Soil samples may furthermore be assessed (using standard procedures) for: (1) textural classes, (2) exchangeable $\mathrm{Na}, \mathrm{K}, \mathrm{Ca}$ and $\mathrm{Mg}$, (3) organic matter content (\% carbon), and (4) water $\mathrm{pH}$. These soil properties are known to influence Tebuthiuron fate and behavior in soil (Emmerich et al., 1984). Lastly, soil seed bank sampling coupled with seed viability testing could establish the availability of viable seed of the affected shrub species.

\section{Acknowledgements}

We thank Wiaan van der Linde for supplying information and Deon Joubert (Park Manager of MoNP) for supporting the investigation. We also thank Rooipoort Nature Reserve management (Andrew Stainthorp and Truia Vermeulen) for supplying rainfall data.

\section{References}

Adams, M. E. (1967). A study of the ecology of Acacia mellifera, A. seyal and Balanites aegyptica in relation to land-clearing. Journal of Applied Ecology, 4, 221-237. http://dx.doi.org/10.2307/2401420

Beste, C. E. (1983). Herbicide handbook of the Weed Science Society of America (5th ed). WSSA, Champaign, IL.

Bezuidenhout, H. (1994). An ecological study of the major vegetation communities of the Vaalbos National Park, Northern Cape. 1. The Than-Droogeveld section. Koedoe, 37, 19-42. http://dx.doi.org/10.4102/koedoe.v37i2.335

Bezuidenhout, H. (1995). An ecological study of the major vegetation communities of the Vaalbos National Park, Northern Cape. 2. The Graspan-Holpan section. Koedoe, 38, 65-83. http://dx.doi.org/10.4102/koedoe.v38i2.315

Bezuidenhout, H., Bradshaw, P., \& Bradshaw, M. (in press). The landscape units of Mokala National Park, Northern Cape. Koedoe.

Buk, K. G., \& Knight, M. H. (2010). Seasonal diet preferences of black rhinoceros in three arid South African National Parks. African Journal of Ecology, 48(4), 1064-1075. http://dx.doi.org/ $10.1111 / 1365-2028.2010 .01213$

Canadian Council of Ministers of the Environment. (1999). Canadian water quality guidelines for the protection of agricultural water uses: Tebuthiuron. In Canadian environmental quality guidelines. Publication No. 1299, Canadian Council of Ministers of the Environment, Winnipeg.

Chang, S. S., \& Stritzke, J. F. (1977). Sorption, movement and dissipation of Tebuthiuron in soils. Weed Science, $25,184-187$.

Donaldson, C. H. (1967). Bush encroachment with special reference to the Black thorn problem of the Molopo area, Department of Agricultural Technical Services, Armoedsvlakte Research Station, Vryburg, South Africa.

Dow AgroSciences. (2003). Material safety data sheet: Molopo 200 GG, Document no. PS 057, Dow AgroSciences LLC, Indiana, USA. 4.

Dow AgroSciences. (2009). Tebuthiuron Technical Manual, Internal document, Dow AgroSciences LLC, Indiana, USA. 158.

Emmerich, W. E., Helmer, J. D., Renard, K. G., \& Lane, L. J. (1984). Fate and effectiveness of Tebuthiuron applied to a rangeland watershed. Journal of Environmental Quality, 13, 382-386. http://dx.doi.org/10.2134/jeq1984.00472425001300030012x

Extoxnet. (1993). Pesticide information profile: Tebuthiuron, Extension Toxicology Network, Cornell University. $\begin{array}{llll}\text { Retrieved November } & 24, & \text { 2013, }\end{array}$ http://pmep.cce.cornell.edu/profiles/extoxnet/pyrethrins-ziram/tebuthiuro 
Fabricius, C., \& Van den Berg, P. (1993). The phenology of some locally browsed species in an arid savanna. Bontebok, 8, 31-32.

Johnsen, T. N., Jr., \& Morton, H. L. (1989). Tebuthiuron persistence and distribution in some semiarid soils. $\begin{array}{lllll}\text { Journal of } & \text { Environmental }\end{array}$ http://dx.doi.org/10.2134/jeq1989.00472425001800040006x

Joubert, D. F., Rothauge, A., \& Smit, G. N. (2008). A conceptual model of vegetation dynamids in the semiarid Highland savannah of Namibia, with particular reference to bush thickening by Acacia mellifera. Journal of Arid Environments, 72, 2201-2210. http://dx.doi.org/10.1016/j.jaridenv.2008.07.004

Koch, S. O., Solomon, M., van Jaarsveld, A. S., Fairbanks, D. H. K., Castley, J. G., \& Knight, M. H. (1999). Vaalbos National Park: replacement options, Internal report, Kimberley Scientific Office, South African National Parks, Kimberley.

Kraaij, T., \& Ward, D. (2006). Effects of rain, nitrogen, fire and grazing on tree recruitment and early survival in bush-encroached savanna. Plant Ecology, 186, 235-246. http://dx.doi.org/10.1007/s11258-006-9125-4

Masubelele, M. L., Hoffman, M. T., Bond, W., \& Burdett, P. (2013). Vegetation change (1988-2010) in Camdeboo National Park (South Africa), using fixed-point photo monitoring: The role of herbivory and climate. Koedoe, 55(1), Art. \#1127, 16 pages. http:// dx.doi.org/10.4102/koedoe. v55i1.1127

Meyer, K. M., Wiegand, K., Ward, D., \& Moustakas, A. (2007). The rhythm of savanna patch dynamics. Journal of Ecology, 95(6), 1306-1315. http://dx.doi.org/10.1111/j.1365-2745.2007.01289.x

Rainey, D. P., \& Magnussen, J. D. (1976). Photochemical degradation studies with 14 C Tebuthiuron, Unpublished report, Elanco, Lily Research Laboratories, Greenfield, USA.

Rohde, R. F., \& Hoffman, T. M. (2010). Landscape and vegetation change in Namibia since 1876 based on the photographs of the Palgrave Commision. In Schmiedel, U., \& Jurgens, N. (Eds.), Biodiversity in southern Africa 2: Patterns and processes at regional scale (pp. 84-92). Gottingen \& Windhoek: Klaus Hess Publisher.

Van Niekerk, J. P., \& Kotze, T. (1977). Chemical control of bush encroachment by means of aerial spraying. In Proceedings of the Second National Weeds Conference of South Africa (pp. 176-184). A. A. Balkema, Cape Town.

Ward, D. (2005). Do we understand the causes of bush encroachment in African savannas? African Journal of Range and Forage Science, 22(2), 101-105. http://dx.doi.org/10.2989/10220110509485867

Wilson, T. B., \& Witkowski, E. T. F. (1998). Water requirements for the germination and early seedling establishment in four African savanna woody plant species. Journal of Arid Environments, 38, 541-550. http://dx.doi.org/10.1006/jare.1998.0362

\section{Copyrights}

Copyright for this article is retained by the author(s), with first publication rights granted to the journal.

This is an open-access article distributed under the terms and conditions of the Creative Commons Attribution license (http://creativecommons.org/licenses/by/3.0/). 